\title{
Investigation of Anti-Sickling Effect of Henna In-Vitro
}

\author{
Hawra Moosa Abdul Ali Al Lawati* and Shakila Ashraf \\ Department of Hematology, Sultan Qaboos University, Oman
}

Submission: August 10, 2017; Published: September 08, 2017

*Corresponding author: Hawra Moosa Abdul Ali Al Lawati, Department of hematology, Sultan qaboos University, Muscat, Oman, Email: shakila_ashraf@hotmail.com

\begin{abstract}
Sickle cells anemia is a common disease in Oman. Sickle cell disease is characterized by the formation of sickle shaped cells. Sickle cells obstruct blood vessels and reduce oxygen transportation this is illustrated by severe painful crises. It was suggested that henna (Lawsonia inermis) can inhibit the formation of sickle cells. Lawsone (2-Hydroxy-1,4-Naphthoquinone) is the molecule responsible for anti-sickling activity of henna by increasing oxygen affinity of red blood cells. This project aimed to investigate the ability to henna to reduce the formation of sickle cells in low oxygen tension conditions. The anti-sickling activity of henna was carried out by incubating aqueous and methanolic henna extracts with sickle cell disease patient's whole blood. Then $2 \%$ sodium bisulphite was added to reduce oxygen tension. After that, the percentage of sickled cells to normal red blood cells was observed at 30 minutes intervals. Henna showed a delay in sickling process in $84 \%$ of the tested samples. According to the results significant antisickling activity was demonstrated by the henna extracts. Both aqueous and methanolic henna extracts showed the ability to delay sickling for about an hour.
\end{abstract}

Keywords: Henna; Lawsonia inermis; Anti-sickling

Abbreviations: SCD: Sickle Cell Disease; Hb: Hemoglobin; SCA: Sickle Cell Anemia; RBCs: Red Blood Cells

\section{Introduction}

Sickle cell disease (SCD) is an autosomal recessive genetic disorder. It is characterized by a point mutation in $\beta$ globin gene on chromosome 11 at the $6^{\text {th }}$ position in which, the amino acid glutamic acid is substituted by the amino acid valine. This mutation leads to the formation of hemoglobin $(\mathrm{Hb}) \mathrm{S}$. Each hemoglobin molecule has four globin chains. Hb A has two chains and two chains but in SCA due to the mutation in chains so, $\mathrm{Hb} \mathrm{S}$ will be formed instead of $\mathrm{Hb} \mathrm{A}$. $\mathrm{Hb} \mathrm{S}$ has two chains and two mutated chains. Each human being inherits two $\beta$ globin genes, one from each parent. Therefore, Sickle cell anemia (SCA) presents in two states, heterozygous and homozygous. In heterozygous state, there is an inheritance of only one defective gene which results in a mild disease form called sickle cell trait. In homozygous state, there are two defective genes which result in a disease form called sickle cell disease [1].

Sickle cell mutation is common in Omani population. The incidence rate of SCD and sickle cell trait was found to be $0.3 \%$ and $4.8 \%$ respectively [2]. The main feature of SCD is sickling, where red blood cells (RBC) change their biconcave shape into sickle shape or other abnormal shapes. RBC change their shape due to hemoglobin polymerization during deoxygenation in low oxygen tension conditions. The intensity of sickling mechanism depends on initial hemoglobin concentration in the cell as well as the rate of deoxygenation. Sickling results in elevation of RBC rigidity and density and in reduction of RBC deformability. Patients with SCD have painful crises when $\mathrm{Hb} \mathrm{S}$ is polymerized and lead to vaso-oclussion [3]. Sickling is a complex mechanism that depends on many events. Some of the events enhance and increase the severity of other events. These events are Hb S polymerization, induction of membrane transport channel abnormalities, endothelial adhesion and nitric oxide reduction [3].

\section{Sickle Cell Disease Therapy}

There is no cure for SCD but there are some supportive medications to manage the severity of the disease and to reduce the frequency of the crisis. SCD can be managed by blood transfusion, body hydration and sickling inhibition. Sickling inhibition can be attempted by preventing $\mathrm{Hb} \mathrm{S}$ polymerization, induction of membrane changes and promotion of capillary flow [4].

Prevention of $\mathrm{Hb} \mathrm{S}$ contact and polymerization can be achieved by the use of: covalent and non-covalent agents to prevent $\mathrm{Hb} \mathrm{S}$ polymerization, prevention of deoxy $\mathrm{Hb} \mathrm{S}$ formation 
by improving oxygenation and increasing oxygen affinity and reduction of $\mathrm{Hb} \mathrm{S}$ concentration by diluting intracellular hemoglobin, preventing cellular dehydration, promoting the synthesis of other hemoglobins, bone marrow transplantation and cord blood transplantation. Membrane changes can be done to achieve sickling inhibition. Those membrane changes can be; enhancement of membrane stability, improvement of RBC deformability, improvement of sickle cells filterability and inhibition of some membrane channels [4].

\section{Henna}

Henna or mehndi, species name Lawsonia inermis linn. the species is also referred to as L.alba and L.rubra. Henna is a shrub that needs hot climate to grow. It is cultivated in tropical and subtropical areas of Asia and Africa. Henna's dried leaves are used as a dye to stain hair, nails and skin [5]. The Key chemical constituents of Henna leaves are: sugars, lawsone, resin, fraxetin, tannin, gallic acid and coumarins [6].

\section{Lawsone}

Lawsone (2-Hydroxy-1,4-Napthoquinone) is the chemical component of henna that is responsible for dying. The more lawsone concentration the deeper henna stains. Lawsone concentration in henna leaves is usually between 1-2\%. Lawsone concentration is more in leaves of henna plant that are cultivated in hot climates [7]. Lawsone can be activated when preparing henna paste by the addition of hot water, lemon juice, clove, tea and other essential oils to get darker stain [8]. It also has an antisickling activity [9].

\section{Medicinal Uses of Henna}

Henna has bacteriostatic, fungistatic and anti-inflammatory activity. Pure natural henna hardly ever causes contact hypersensitivity. Usually dermatitis and contact hypersensitivity that happen after henna application is due to other chemicals (like, papra-phenylenediamine and para-toluylenediamine) that are added to henna to increase color intensity and reduce application time [10]. There is a study that shows henna can protect SCD patients from sickling due to, the increase in oxygen affinity of sickle cells which is induced by lawsone. It was found that in low oxygen tension lawsone had the ability to increase oxygen affinity of irreversible sickle cells. The increase in $\mathrm{Hb} \mathrm{S}$ oxygen affinity is useful.

It is an enhancement in the attraction of oxygen to $\mathrm{Hb} \mathrm{S}$. This will help RBC to resist deoxygenation and will reduce the amount of polymerization. Also, it was found that lawsone was reactive with singlet oxygen. Free oxygen radicals are generated upon hemoglobin oxidation. Those radicals can induce oxidative injury and damage RBC membrane. In normal persons those oxygen radicals are neutralized by 2,3-diphosphogycerate to form hydrogen peroxide. Then catalase will convert hydrogen peroxide to water. But, the enzymes 2,3-diphosphogycerate and catalase are found in less concentrations in SCD patients $[9,11]$.
The aim of this study was to investigate the affect of aqueous and methanolic henna extracts on blood samples of sickle cell disease patients in-vitro.

\section{Materials and Methods}

The research was done in Sultan Qaboos University. Research duration was 4 months. Evaluation of anti-sickling activity was carried out using a modified method of Olufunmilayo et al. [12].

\section{Henna powder preparations}

Henna leaves were picked from a local Henna tree. The leaves were kept in sunlight for 2 days to dry completely. Then the dried leaves were grinded to form a fine powder.

\section{Henna extraction}

Henna powder was extracted in distilled water and methanol. The extracts were prepared in plastic tubes by mixing $130 \mu \mathrm{g}$ of henna in $10 \mathrm{ml}$ of distilled water and the same was done with methanol. Then they were kept at room temperature for 3 days until the solution evaporates completely. Before doing the experiment aqueous and methanolic henna suspension of concentration of $1.3 \mathrm{mg} / \mathrm{ml}$ was prepared by adding isotonic saline and methanol to extracted henna.

\section{Blood samples}

Whole blood samples were taken from 50 sickle cell disease patients from Sultan Qaboos University Hospital in ethylene diamine tetraacetic acid (EDTA) tubes by venipuncture.

\section{Anti-sickling assay}

$250 \mu \mathrm{l}$ of aqueous henna extracts suspension was added to $250 \mu \mathrm{l}$ of whole blood in plastic test tubes. In another tube $250 \mu \mathrm{l}$ of methanolic henna extracts suspension was added to $250 \mu \mathrm{l}$ of whole blood. The Steps above were done in duplicate and mean of results of the duplicate tests was taken. Negative controls were run with each test sample. Control tubes were prepared by adding $250 \mu$ l of patient's blood with $250 \mu$ l of isotonic saline.

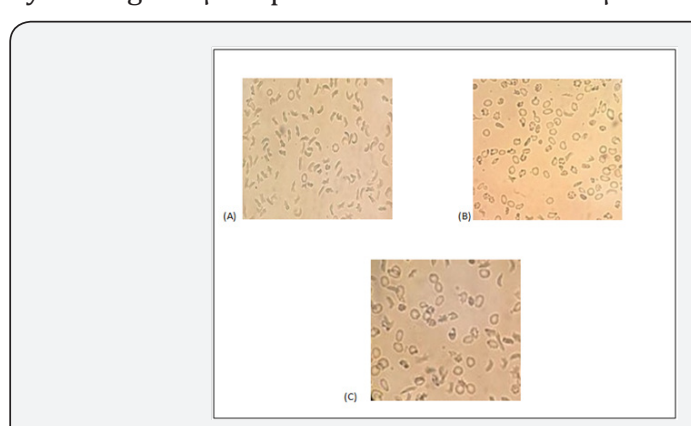

Figure 1: Sickle cells morphology of a sample after 30 minutes incubation with $2 \%$ sodium bisulphite. (A) Negative control. (B) Aqueous henna extracts. (C) Methanolic henna extracts.

All tubes were incubated in a water bath at $37^{\circ} \mathrm{C}$ for 3 hours. After incubation $15 \mu \mathrm{l}$ of $2 \%$ sodium bisulphite was mixed with $15 \mu \mathrm{l}$ of the incubated samples on a slide then it was covered with a cover slip and sealed with a nail varnish (Figure 1). Then the 


\section{Open Access Blood Research \& Transfusion Journal}

slides were observed under the microscope after 30 minutes, 60 minutes and 90 minutes of preparation. 200 cells were counted in each slide and the percentage of sickle cells was calculated and recorded.

The percentage of sickling inhibition was calculated using the following formula [13]:

Sickling inhibition $(\%)=\frac{T c o-T s}{T c o} \times 100$

$\mathrm{Tco}=$ Percentage of sickled cells at time $\mathrm{T}$ on incubation with normal saline control

Ts = Percentage of sickled cells at time $\mathrm{T}$ on incubation with the extracts.

\section{Results}

In this research, 50 blood samples from Omani sickle cell disease patients (28 males and 22 females) were used to test anti-sickling activity of henna extracts. The patients were from different age groups from 1 year to 35 years.

Out of 50 samples analyzed, 42 samples (84\%) showed inhibition induced by henna and 8 samples (16\%) did not show any response to henna. Both methanolic and aqueous extracts showed anti-sickling activity after 30 and 60 minutes following the addition of $2 \%$ sodium bisulphate but, there was no antisickling activity after 90 minutes. After 90 minutes about 99 $100 \%$ of the cells were sickled. Greater anti-sickling activity was observed within 30 minutes of incubation and the inhibition was reduced after 60 minutes.

Mann-Whitney test was used to test the significance of mean anti-sickling activity of aqueous and methanolic extracts after 30 and 60 minutes incubation. No significant difference was found ( $p>0.05$ ). Kruskal-Wallis $\mathrm{H}$ test was used to test the significance difference between mean sickling inhibitions and the level of $\mathrm{Hb}$, $\mathrm{MCV}, \mathrm{MCH}, \mathrm{MCHC}, \mathrm{Hb} \mathrm{S}, \mathrm{Hb} \mathrm{A}, \mathrm{HbA}_{2} \mathrm{Hb} \mathrm{F}$ and hydroxyurea intake. There were no significant effect of MCV, MCHC, $\mathrm{Hb} \mathrm{S}, \mathrm{Hb} A$, and HbA2 ( $>>0.05)$ on the rate of sickling inhibition. However, there were significant difference between mean sickling inhibition and MCH $(\mathrm{p}<0.05), \mathrm{Hb} \mathrm{F}(\mathrm{p}<0.05)$ and hydroxyurea intake $(\mathrm{p}<0.01)$. It was observed that increase in $\mathrm{Hb}$ F and MCH to certain level and intake of hydroxyurea encouraged anti-sickling activity.

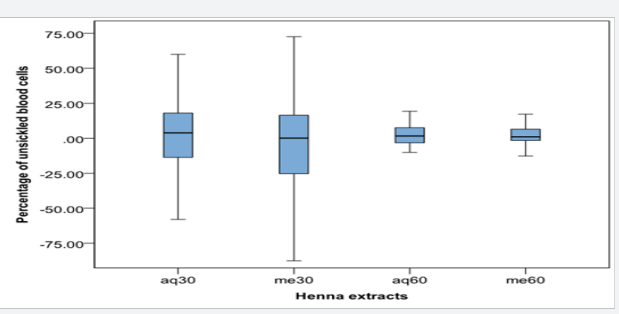

Figure 2: Percentage of unsickled red blood cells in aqueous and methanolic henna extracts after 30 and 60 minutes incubation with $2 \%$ sodium bisulphite. (aq30) aqueous extracts after 30 minutes incubation, (me30) methanolic extracts after 30 minutes, (aq60) aqueous extracts after 60 minutes incubation and (me60) methanolic extracts after 60 minutes.
In both aquoues and methanolic extracts, the level of sickling inhibition was higher within 30 minutes and was less after 60 minutes. All values were means of duplicate determinations (Figure 2).

All samples did not show the same response. Some of the samples were responding in methanolic extracts, some were responding in aquoeus extracts, some responded in all conditions and some did not respond at all. Sickling inhibition of each sample was compared by its own negative control. Percentage of sickling inhibition of all samples was calculated. After 30 minutes of incubation, in aquoeus extracts 29 samples showed resistance to sickling activity and mean of sickling inhibition was $20.7 \%$ and in methanolic extracts 25 samples had an antisickling activity and mean of sickling inhibition was $21.8 \%$. Also, after 60 minutes of incubation, in aquoues extracts 31 samples had an antisickling activity and mean of sickling inhibition was $7.7 \%$ and in methanolic extracts 29 samples had an antisickling activity and mean of sickling inhibition was $7.4 \%$. Mean sickling inhibition of methanolic and aquoeus extracts were close to each other after 30 minutes and after 60 minutes (Table1).

Table 1: Means of sickling inhibition (\%) of samples showed antisickling activity in aqueous and methanolic henna extracts.

\begin{tabular}{|c|c|c|}
\hline $\begin{array}{c}\text { Time of } \\
\text { Incubation } \\
\text { (minutes) }\end{array}$ & $\begin{array}{c}\text { Sickling Inhibition in } \\
\text { Aqueous Henna Extracts } \\
\text { (Concentration:0.13mg/ } \\
\text { ml) }\end{array}$ & $\begin{array}{c}\text { Sickling Inhibition } \\
\text { in Methanolic } \\
\text { Henna Extracts } \\
\text { (Concentration: } \\
\mathbf{0 . 1 3 m g / m l )}\end{array}$ \\
\hline 0 & $0(0)$ & $0(0)$ \\
\hline 30 & $20.7(29)$ & $21.8(25)$ \\
\hline 60 & $7.7(31)$ & $7.4(29)$ \\
\hline 90 & $0(0)$ & $0(0)$ \\
\hline
\end{tabular}

MCH levels of the patients were between $18.7-32.8 p g$. The patients having MCH levels between 22.9-25.9pg had the highest percent of sickling inhibition in both aqueous and methanolic extracts but sickling inhibition was reduced in samples having MCH less than 22.8pg or more than 26pg (Figure 3).

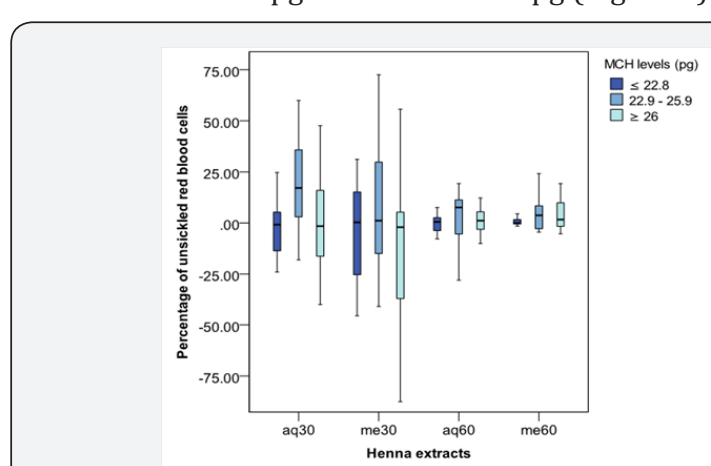

Figure 3: $\mathrm{MCH}$ levels and percentage of unsickled red blood cells in aqueous and methanolic henna extracts.

$\mathrm{Hb} \mathrm{F}$ levels of the patients were between $0.4-23.9 \%$. The group of patients having $\mathrm{Hb}$ F between $6.8-10.7 \%$ had higher percent of sickling inhibition with aquoues and methanolic 
henna extracts but, sickling inhibition was less with patients having $\mathrm{Hb} \mathrm{F}$ less than $6.7 \%$ and more than $10.8 \%$ (Figure 4 ). 15 out of the 50 patients observed in this study were taking hydroxyurea. Sickling inhibition was increased in patients taking hydroxyurea (Figure 5).

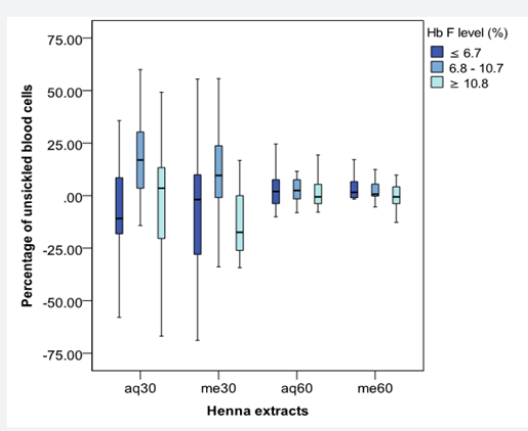

Figure 4: $\mathrm{Hb} \mathrm{F}$ levels and percentage of unsickled red blood cells in aqueous and methanolic henna extracts.

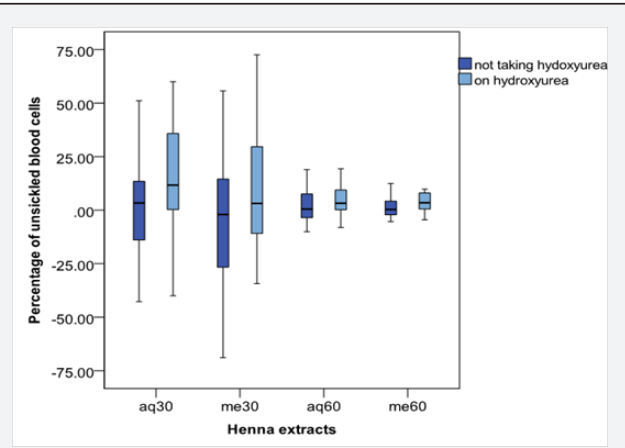

Figure 5: Hydroxyurea intake and percentage of unsickled red blood cells in aqueous and methanolic henna extracts.

\section{Discussion}

It was found that henna has an anti-sickling activity. Henna extracts did not completely stop sickling but it showed a delay in sickling process for about an hour. Means of anti-sickling activity was almost the same in aqueous and methanolic henna extracts (Figure 2). Therefore both extraction methods can be used for anti-sickling activity. The delay in sickling mechanism may be due to lawsones increase in oxygen affinity induced by the reaction of lawsone with oxygen radicals [9].

Anti-sickling effect of henna was encouraged by MCH level between 22.9 - 25.9pg and was reduced when MCH was less than 22.8pg or more than 26pg (Figure 3). Also, Kruskal-Wallis $\mathrm{H}$ test showed that the difference in sickling inhibition at various $\mathrm{MCH}$ levels were hhenna is related to RBC's hemoglobin content. A positive relationship between $\mathrm{Hb} \mathrm{F}$ concentration and antisickling activity was observed. Higher anti-sickling activity of henna was observed in samples having $\mathrm{Hb} F$ level between 6.8 - 10.7\%. Although anti-sickling activity was less when $\mathrm{Hb}$ F was less than $6.8 \%$ and more than $10.7 \%$ (Figure 4). Also, KruskalWallis $\mathrm{H}$ test showed that the difference in sickling inhibition at various $\mathrm{Hb}$ F levels was significant. Hydroxyurea is a drug that activates $\mathrm{Hb} \mathrm{F}$ formation. It was observed that sickling inhibition was increased in patients taking hydroxyurea (Figure 5). And Mann-whitney $U$ test showed that the difference of sickling inhibition is significantly between patients taking hydroxyurea and those not taking hydroxyurea.

The results suggests that anti-sickling activity of lawsone is increased by higher $\mathrm{Hb}$ F levels. Lawsone's anti-sickling activity may be related to $\mathrm{Hb} \mathrm{F}$ and $\mathrm{Hb} \mathrm{F}$ may have the ability to enhance the activity of lawsone. Anti-sickling activity of henna was not influenced by MCV, MCHC, $\mathrm{Hb} \mathrm{S}, \mathrm{Hb}$ A, and $\mathrm{Hb}$ A2 levels. However 8 blood samples either showed very low response or no response at all. The reasons behind these were unknown.

The results of this project are significant in the management of SCD. It may reduce the intensity of the crisis and prevent a good number of RBC from polymerization and sickling. Henna may reduce and inhibit sickling in-vivo if the delay time induced by henna was long enough for the cells to return to lungs and reoxygenate before sickling initiation [14]. In addition, antisickling activity of henna should be higher in-vivo than in-vitro because, the reduction in oxygen tension in-vivo is less than the reduction caused by $2 \%$ sodium bisulphite [15]. Moreover, henna has a short lasting ability to increase oxygen affinity which is beneficial because the long lasting increase in oxygen affinity will cause compensatory erythropoiesis [11]. Moreover compensatory erythropoiesis is unfavorable in SCD because it will increase the severity of the disease. Therefore henna is a valuable supportive therapy for SCD.

\section{Recommendations}

For future work, variation in the henna concentration and variation in the incubation time should be used which can vary the anti-sickling activity. It may be beneficial to compare leaves of different henna plants from different places because henna plants grow at diverse conditions and places that has different characteristics and hence anti-sickling affect might be different. Also, henna from each place has different concentration of its components so, it will be useful to know exact henna composition and components concentration that are more effective in antisickling activity.

In conclusion, this study showed that henna has significant anti-sickling activity. However, the intensity of sickling inhibition is variable among the patients. The inhibition was influenced by $\mathrm{MCH}, \mathrm{Hb} \mathrm{F}$ and hydroxyurea. Anti-sickling activity was higher when MCH was between 22.9 - 25.9pg and when Hb F level was between 6.8 - 10.7\%. Higher anti-sickling activity was observed in patients taking hydroxyurea. It was also observed that $\mathrm{Hb} \mathrm{F}$ was the main parameter that was related to anti-sickling activity of henna.

Values in brackets represents the number of samples that showed anti-sickling activity at that time. 


\section{References}

1. Rodak BF, Fritsma GA, Doig K (2007) Hematology: Clinical principles and applications ( $3^{\text {rd }}$ Edn). Missouri: Westline Industrial Drive, USA.

2. Alkindi S, Alzadjali S, Almadhani A, Daar S, AlHaddabi H, et al. (2010) Forecasting Hemoglobinopathy Burden Through Neonatal Screening in Omani Neonates. Hemoglobin 34(2): 135-144.

3. Embury SH, Hebbel RP, Mohandas N, Steinberg MH (1994) Sickle cell disease: Basic principles and clinical practice. New York: Raven Press, USA.

4. Serjeant GR, Serjeant BE (2001) Sickle cell disease ( $3^{\text {rd }}$ Edn). Oxford: Oxford University Press, India.

5. Plant Kingdom Classification.

6. The chemical constituents of henna.

7. Lawsone $\sim$ From Lawsonia inermis (henna leaves).

8. The henna colouring process.

9. Clarke DT, Martin MM, Martin MM (1986) The Anti-sickling Drug Lawsone (2-OH-1,4-naphthoquinone) Protects Sickled Cells Against Membrane Damage. Biochemical and biophysical research communications 139(2): 780-786.
10. Avijit H (2002) Adverse Reaction to Henna. Indian journal of pharmacology 34: 436-437.

11.Weng W, Aprelev A, Briehl RW, Ferrone FA (2008) Universal Metastability of Sickle Hemoglobin Polymerization. J Mol Biol 377(4): 1228-1235.

12. Olufunmilayo EA, Adelodun LK, Oladimeji PR (2010) In-vitro antisickling activities and phytochemical evaluation of Plumbago zeylanica and Uvaria chamae. African Journal of Biotechnology 53(9): 9032-9036.

13. Moody JO, Ojo 00, Omotade 00, Adeyemo AA, Olumese PE, et al. (2003) Anti-sickling Potential of a Nigerian Herbal Formula (Ajawaron HF)and the Major Plant Component (Cissus populnea L. CPK). Phytotherapy research 17(10):1173-1176.

14. Mozzarelli A, Hofrichter J, Eaton WA (1987) Delay time of hemoglobin $\mathrm{S}$ polymerization prevents most cells from sickling in vivo. Science 237(4814): 500-506.

15. Egunyomi A, Moody JO, Eletu OM (2009) Antisickling activities of two ethnomedicinal plant recipes used for the management of sickle cell anemia in Ibadan, Nigeria. African journal of biotechnology 8(1): 2025.

\section{Your next submission with Juniper Publishers} will reach you the below assets

- Quality Editorial service

- Swift Peer Review

- Reprints availability

- E-prints Service

- Manuscript Podcast for convenient understanding

- Global attainment for your research

- Manuscript accessibility in different formats ( Pdf, E-pub, Full Text, Audio)

- Unceasing customer service

Track the below URL for one-step submission https://juniperpublishers.com/online-submission.php 